University of Wollongong

Research Online

Faculty of Law, Humanities and the Arts Papers (Archive)

Faculty of Arts, Social Sciences \& Humanities

$1-1-2019$

Sex trafficking to the Federated Malay States 1920-1940: from migration for prostitution to victim or criminal?

Vicki D. Crinis

University of Wollongong, vcrinis@uow.edu.au

Follow this and additional works at: https://ro.uow.edu.au/lhapapers

Part of the Arts and Humanities Commons, and the Law Commons

Research Online is the open access institutional repository for the University of Wollongong. For further information contact the UOW Library: research-pubs@uow.edu.au 


\title{
Sex trafficking to the Federated Malay States 1920-1940: from migration for prostitution to victim or criminal?
}

\author{
Abstract \\ This article analyses the relationships between the colonial government in the Federated Malay States \\ (FMS), international social movement organisations, the League of Nations and sex trafficking. While \\ there is considerable scholarship on social movement organisations and the League of Nations, far less \\ is known about the links between internationalism, colonialism and sex trafficking. After the First World \\ War, trafficking became the focus of social movement organisations and the League of Nations, but \\ colonial regulation of prostitution and tolerated brothels complicated international responses to \\ trafficking. Colonial administrators saw prostitution as an essential service, whereas feminist and \\ international social movement organisations saw prostitution as an impetus for trafficking. This article \\ engages with newspaper reports, colonial correspondence and Chinese petitions, archival material from \\ social movement organisations, and reports by the Association of Moral and Social Hygiene, the League \\ of Nations and the Chinese Secretariat to extend the literature on the historiography of trafficking and the \\ British Empire.

\section{Disciplines} \\ Arts and Humanities | Law

\section{Publication Details} \\ Crinis, V. (2019). Sex trafficking to the Federated Malay States 1920-1940: from migration for prostitution \\ to victim or criminal?. The Journal of Imperial and Commonwealth History, Online First 1-23.
}




\title{
Sex Trafficking to the Federated Malay States 1920-1940: from migration for prostitution to victim or criminal?
}

\begin{abstract}
This article analyses the relationships between the colonial government in the Federated Malay States (FMS), international social movement organisations, the League of Nations and sex trafficking. While there is considerable scholarship on social movement organisations and the League of Nations, far less is known about the links between internationalism, colonialism and sex trafficking.
\end{abstract}

After the First World War, trafficking became the focus of social movement organisations and the League of Nations, but colonial regulation of prostitution and tolerated brothels complicated international responses to trafficking. Colonial administrators saw prostitution as an essential service, whereas feminist and international social movement organisations saw prostitution as an impetus for trafficking. This article engages with newspaper reports, colonial correspondence and Chinese petitions, archival material from social movement organisations, and reports by the Association of Moral and Social Hygiene, the League of Nations and the Chinese Secretariat to extend the literature on the historiography of trafficking and the British Empire.

Key Words: Trafficking, Migration, Malaya, League of Nations, Association of Moral and Social Hygiene, National Vigilance Association, Internationalism, Colonialism

\section{Introduction}

Women migrating for prostitution and the trafficking of women and girls are inextricably linked, and are difficult to separate when discussing the movement of women and girls from China, Japan and the Dutch East Indies to the Federated Malay States (FMS). In pre-colonial times, traders, transient workers and sojourners followed a long-established migration path 
from China and Japan to Southeast Asia. Colonial rule and economic expansion, however, increased the movement of male workers to the tin mining towns and capital cities of Selangor, Perak, Pahang and Negeri Sembilan in colonial Malaya. The increasing numbers of transient male labourers sustained the movement of women and girls for sexual and domestic work. The Colonial Office approved the Chinese Protectorate for the specific purpose of mediating Chinese labour and addressing brothels and prostitutes. ${ }^{1}$ The Protectorate adopted a hybrid approach to female migration and immigration: women of age were allowed through to work in the brothels and minor girls were rescued under The Protection of Women and Girls legislation. The colonial officials, however, found it difficult to ascertain the difference between women migrating for prostitution and the women and girls trafficked for prostitution.

The line between being 'trafficked' and 'migrating' for prostitution is not black and white. It is impossible to know whether individual women and girls were trafficked or came of their own accord, because they left no records or diaries. There is certainly evidence of trafficking throughout the archives; the Chinese Protector rescued about 50 under-aged girls a year, and there are records of court cases where traffickers were incarcerated for the kidnapping, rape and sale of women and girls. There is also evidence that women came of their own accord. Court cases recorded women acting on their own and petitions in the archives give voice to women and girls. In one petition, from a husband to the Colonial Resident, we hear women's agency loud and clear.

My wife came from China and lived in Pudu four years ago, during [sic she was in Puda she used to trade in immoral purposes and sometime in May last year I sent her to China to look after my old mother. When she went home for a few months she sold my daughter, and in December she absconded [sic] my house, she was found in Pudu again in June this year carrying the same trade as before. I think 
the Protector of Chinese should deal with a woman who is trading in immoral purpose without a license as otherwise the family principal would be corrupted. ${ }^{2}$

While this was not the experience of all women and girls, this petition tells us that not all women were victims of trafficking. It is important nevertheless to understand that the term 'trafficking' is problematic. Trude Jacobsen rightly disputes the notion that trafficking and prostitution is an actual history of deception, coercion and lack of agency. ${ }^{3}$ Women and girls had different backgrounds and motivations: some sought an escape from husbands or poverty; some girls who were too young to understand their fate were sold to traffickers; and others went to appease their parents and send home a remittance. Secondary sources argue that family and communal responsibilities were a significant part of the culture of Chinese and Japanese peoples. Women and girls who migrated for prostitution were, for the most part, daughters of impoverished rural families in drought-stricken provinces of China and Japan who 'seemed to subscribe to their subordination'. ${ }^{4}$

This article, however, is not a history of the women and girls concerned, but an outline of the struggle between internationalism and colonialism around trafficking and prostitution, and how this affected the women and girls. The first part of the article provides a background of social movement organisations and their connections to trafficking and prostitution. It connects these organisations to the League of Nations and its international mission around slavery and trafficking. The second section highlights the contradictions between British imperialism and international humanitarianism. It shows the power of social movements that influenced the British government's decisions around tolerated brothels and the politics accompanying these actions. Using the valuable Association of Moral and Social Hygiene records and British colonial reports as well as newspapers, this section draws attention to social movement 'intrusions' into the masculine colonial frontier and the high levels of 
conflict between the colonial state, the feminist movement and the social movement organisations. The last section highlights the difficulties it creates for colonised women and girls after trafficking and prostitution are outlawed. This section questions the extent to which internationalism precipitated legal and social actions that halted the traffic in Chinese women and girls, or whether it limited the freedom of women and girls.

\section{Trafficking: Social movement organisations and the League of Nations}

After the First World War, social movement organisations increased their humanitarian pursuits across the empire. Daniel Gorman rightly claims that the shift to more constructive imperialism was about addressing the fall-out from imperialism, industrialisation and uneven economic development. ${ }^{5}$ Social movement organisations moved away from religion (although many activists were Christians) and extended the care usually reserved for family and friends to include strangers. These philanthropic quests led to changes in the power structures in the Empire. According to Susan Pederson, there was a turn from the political and economic convictions of men, to the material, social and moral interests of women. ${ }^{6}$ The growth in social movement organisations was also seen as arising from the women's movement in Britain. Women's interests in social movement activities started with the Suffragette movement. Women worked hard to win the electoral vote, however, the number of women in political parties remained low. Women preferred to join humanitarian organisations around issues to do with women and children, rather than engage in male-dominated politics. By the 1920s, middle-class women's attention was focused on women's inequality in the United Kingdom (UK) and tolerated brothels in the British Empire. 
Magaly Garcia refers to women as 'moral entrepreneurs' or reformers. In Garcia's words, both men and women engaged in 'the moral recruitment of women'. ${ }^{7}$ Basing her study on Howard Becker's concept of 'moral entrepreneurs' and Ethan Nadelmann's 'transnational moral entrepreneurs,' moral reformers operate with ethics in seeking to bring in new rules to deal with a perceived great evil. ${ }^{8}$ Most reformers believe they have the moral qualities to address social problems and recruit like-minded adults to the cause. The problem with moral entrepreneurs, however, is that these reformers have more power than those they wish to reform, and they tend to work within the construction of 'victims and perpetrators'. There are grey areas between the trafficked and the traffickers, as many traffickers and procurers have also been 'victims'.

The two British groups which played a role in combatting trafficking and prostitution were the National Vigilance Association (NVA) and the Association for Moral and Social Hygiene (AMSH). The following section outlines the background to these organisations and their association with the League of Nations.

The NVA (a mostly male-dominated organisation) was modelled in part on the work of the abolitionists from the late 1890 s. ${ }^{9}$ It was orchestrated to oversee the 1895 Criminal Law Amendment and the age of consent legislation in Britain. The NVA was also concerned with the traffic in women and children and took the campaign to the international level. This resulted in a conference organised by the International Bureau for Suppression of Traffic in Women and Children (IBSTWC) in 1899, which became the umbrella for national voluntary organisations. Over the next decade, at two conferences held in 1904 and in 1910, nationstates were entreated to legislate structures to meet international standards under the International Agreement for the Suppression of White Slave Trade. The NVA called for an 
end to sexual immorality and the traffic in women and girls. It sought to warn young girls about 'stranger danger' and their vulnerability at the hands of sexual 'predators' by painting a picture of the conniving trafficker.

The Association for Moral and Social Hygience (AMSH), formerly the International Abolitionist Federation, originated with Josephine Butler and the abolition of the Contagious Diseases Ordinance and prostitution. The association, formed in 1915, was more concerned with laws to protect the rights of women and children and to bring sexual equality between men and women. In 1919, the AMSH began a public campaign against regulated prostitution within the British Empire. ${ }^{10}$ It was particularly opposed to the street allocation for brothels and collected first-hand reports from Asia and Southeast Asia.

Julia Laite draws attention to the NVA's 'sexualised xenophobia' around trafficking and unwanted foreign immigration. ${ }^{11}$ Unlike NVA activists, who called for the criminalisation of all things immoral including the 'continental prostitute,' the AMSH continued to be abolitionist in its mission and preferred justice and equality for all women and girls. While it wanted to stop the traffic in women and girls, it did not want the state to punish women or to control their bodies. Its objective was to raise the moral standing of the relationship between men and women. According to the AMSH, the British legal system 'manufactured prostitutes' through naming and shaming women and girls. ${ }^{12}$ Under the Solicitation law, which it strongly opposed, once a female was labelled a 'common prostitute', this title was never disputed and allowed for levels of violence against women and girls who lived outside the controls of the family. 
Anne McClintock, writing about race, gender and sexuality in the Butler-Victorian period, argues that many middle-class women saw the marriage contract and prostitution as a system where the patriarchal state held power over women's bodies. ${ }^{13}$ The fundamental issue is an economic one. The sex purchasing power of men over women driven by financial pressure into selling sexual services for money did not sit well with the women. According to McClintock, for many Victorian women, 'prostitution became the projection of middle-class women's anxieties and figured as objects of grief and rage'. ${ }^{14}$ Although most moral entrepreneurs were not familiar with the lives of prostitutes, they served as a projection of British women's sense of vulnerability.

\section{League of Nations and trafficking}

The League of Nations was established in the 1920s to assist the peace process after the First World War, and to address social issues such as the remnants of slavery, opium addiction and sex trafficking. Its Opium and Social Questions Department, under the leadership of trained nurse and sociologist Rachel Crowdy (1919 to 1931), opened a space for women's groups working in the field of trafficking and prostitution to be appointed as experts. The AMSH was distinctive in its mandate and influential in advising the League of Nations Social Department on trafficking. ${ }^{15}$ It promoted the abolitionist position against brothel prostitution. However, the League's Committee of Experts saw prostitution as the nation-states' problem rather than an international issue. The League so far, had not seen the contradictions between humanitarian pursuits around trafficking and colonial regulated brothels in the British Empire. The League introduced the Suppression of Trafficking Bill in 1921 to stop trafficking of women and girls, but the regulation of prostitution remained under state control. The legislation encompassed the 1904 Agreement and the 1910 Convention, and raised the age of 
consent to 21. Accordingly, trafficking was 'the direct or indirect procuration and transportation for gain to a foreign country of women and children for the sexual gratification of one or more persons'. ${ }^{16}$ According to Stephen Legg, the League pushed nation-states to adopt a legal model that standardised anti-trafficking measures and explicitly defined transnational trafficking as an international crime to be addressed across nation-states. ${ }^{17}$ More than 33 countries signed the agreement, but France declined due to its regulatory policies around prostitution. The League of Nations provided the framework for measuring trafficking in women and children and set out rules to address trafficking. Nation-states were asked to fill out a questionnaire on trafficking every year and send reports to Geneva for collation. This enabled the Committee of Experts to estimate the extent of trafficking or, indeed, if there was any trafficking, as most of the reports had come from newspapers. ${ }^{18}$ The League did not suggest changes in national politics around prostitution, but made immigration ports hostile areas for traffickers.

Crowdy's first task was to set up the Advisory Committee on the Traffic in Women and Children (1921-24) to investigate the nature and scope of international trafficking and antitrafficking measures. By 1924, a collection of reports on international trafficking was released and provided valuable information on the movements of women and girls, the names of the traffickers and their convictions. But while reports provided evidence of trafficking, the League needed to understand how trafficking operated on the ground. In the following year, the American Social Hygiene Association provided funding to the Committee of Experts to send experts into the field for investigation. It appears social movements shared information and copied each other's strategies around trafficking. 
The enquiry interviewed 5000 persons from 112 countries in Northern and Southern Europe and Central America and took two years. ${ }^{19}$ The first of its two-volume report was released in 1926. The Committee of Experts found no evidence to substantiate an international system of traffic in women and children. While there was third-party involvement, there was no evidence of organised crime syndicates. ${ }^{20}$ The researchers claimed, however, that trafficking included levels of deception and coercion, because the women or girls concerned were unaware of the conditions under which they were expected to work.

The release of the second volume proved controversial, as South American countries claimed the reporting was biased against non-white developing countries. This was certainly the case, as Crowdy interpreted the reports from both the countries and the trafficked women through a modern eugenics lens. Accordingly, states most likely to have problems were not democratic. Crowdy explained 'the greatest demand for these unhappy girls comes from countries where one was not accustomed to regarding as in the van of civilisation'. ${ }^{21}$ Women and girls from these countries were seen as 'feeble-minded', easily influenced and confused over what was morally right and wrong. ${ }^{22}$ According to Crowdy, these girls were the victims most likely to succumb to exploitation. This line of thinking chimed in with the rhetoric of superior and inferior countries and races, but did little to address the trafficking of women and girls.

The League of Nations and the Trafficking in the East Report

Crowdy looked to the trafficking situation in the East to prove her theory. Even though Britain asked to exclude the British colonies and Protectorates before signing the Convention, in the 1930s the League Commission of Inquiry was extended to India, Hong Kong, the Straits 
Settlements (Singapore, Malacca and Penang) and Malaya (FMS and Unfederated Malay States (UFMS). Unlike the investigations in Northern and Southern Europe and Central America, Crowdy organised experts to interview police officials, colonial officers, personnel from social organisations, magistrates and immigration officials. But she felt it unnecessary to hear the voices of the women and girls in Southeast Asia. ${ }^{23}$ By the time the report was released in 1932, Crowdy had left the League and her replacement, a male expert, concluded that women and children were being bought and sold in the East, and also transported to Australia and South America.

The central facts of the report elaborated on the profound differences between the East and the West, primarily on cultural issues and Western democracies. The Chinese were also racialised as a 'slave girl' culture because it was assumed that 'in China, parents sell their children, particularly girls who contribute to the development of international traffic'.24 According to the report, putting an age limit on young girls entering brothels was rarely successful, because Chinese girls adopted at a young age as domestic servants (Mui Tsai) were married to family members or sold to brothels once they reached puberty. ${ }^{25}$ So they could enter the country as Mui Tsai and then end up working in the brothels. The Committee resolved to remove the age limit in the 1921 Convention, so that the traffic of women and girls of any age constituted a criminal activity. Removing the age limit, however, created a problem for the countries with licensed brothels, as it was no longer acceptable for women of age to migrate for prostitution. The League started to understand the dislocation between Empire building and humanitarianism and conceded that 'the existence of licensed or officially recognised brothels is undoubtedly an incentive both to national and international traffic in women'. ${ }^{26}$ Internationalism, in this case, interfered with sovereign laws around prostitution, and made a case for the abolition of all brothels. 
Subsequently, the League, like the AMSH, worked towards outlawing brothels to end trafficking of women and children. It viewed it as immoral, indecent and misogynistic for the British government to regulate prostitution, a proven incentive for trafficking. They called for the abolition of all brothels and tighter action against trafficking in all the Far Eastern countries. $^{27}$

\section{Colonial Masculinity versus Feminist abolition}

In response to internationalism, colonial administrators argued that the colonies were a masculine space where prostitution was seen as an intimacy essential to calm the colonised migrant labour force. Instead of constructing permanent family communities which required maintenance and capital expenditure, the Colonial Government allowed a transient male population and brothel houses to flourish. In 1919, in the state of Selangor alone, there were 46 Chinese brothels with 661 inmates listed in the Chinese Secretariat Reports. Of these, 38

were in Kuala Lumpur and the rest were in the tin mining towns in Selangor. ${ }^{28}$ Perak had similar numbers to Selangor, while the numbers in Pahang and Negeri Sembilan were considerably less due to fewer migrant male workers. Nonetheless, brothels and prostitutes continued to increase in these states, and were divided according to race. The Japanese women and girls were considered superior with regard to cleanliness to the Chinese, and their clients were mainly European and middle-class men. On the other hand, the Chinese women and girls provided sexual services to the mostly Chinese male labour force. The hyper-masculine culture in tin mining towns was entrenched in a culture of violence against women, clan-based violence, gambling, and the consumption of alcohol and opium. The violence associated with trafficking and regulated prostitution, however, was silenced in the rhetoric of colonial 
paternity. According to the Chinese Protector, the immigration of women for prostitution was regulated in the interest of the women and girls.

Permission to a prostitute was always refused unless the local Protectorate officer was satisfied that the applicant had already become a habitual prostitute either outside the Federated Malay States as a known or 'sly' prostitute or within the Federated Malay States as a 'sly' prostitute. It is however probable that most of those who were allowed to prostitute had originally been the victims of traffickers. ${ }^{29}$

However, it was more about giving male workers access to prostitutes. Women of age were isued a ticket to practise prostitution if requested, and 'all known prostitutes were interviewed during the year and given the opportunity to make complaints or abandon their course of life. $^{30}$ In this interview, the colonial officer was patronising on the one hand, but was also attempting to distinguish trafficking from sex work. The Chinese Protectorate attempted to save minors and return them to their families in China, or to place them in rehabilitation homes to be trained in morality until they reached the age of 18 . If the Protector was suspicious of forced trafficking, the girl was placed on a security bond. If the girl moved to another state, her photograph was sent to the Protector for verification upon arrival, to ensure the minor did not end up in a brothel. ${ }^{31}$ According to the Protector at Kuala Lumpur, Selangor:

Constant communication is kept up with the Protectorates in the SS [Straits Settlements] and the FMS with regards to the movements of prostitutes, female and child immigrants and girls under Security Bonds under the Women and Girls Protection Enactment. These communications amount to many hundreds per year. ${ }^{32}$

While the safety and welfare of young girls was a priority, it was also essential to keep 'seasoned prostitutes' under control. ${ }^{33}$ The literature on this period argues that the prostitute body was imagined as a diseased body and was treated by the medical profession in the 
interests of maintaining the health of the colony. ${ }^{34}$ According to the colonial surgeon, the numbers of people infected with venereal disease continued to escalate during and after the First World War. But according to Levine, the problem was more to do with colonial control around the brothels, rather than the spread of disease. ${ }^{35}$

A flaw in the Protection of Women and Girls legislation meant the Protector had no jurisdiction over brothel keepers to send sick women for treatment. ${ }^{36}$ In a letter to the Colonial Secretary of State, Mr A. B. Jordan, the Chinese Protector gave an example of the situation. In 1925, two brothel owners were accused of keeping sick girls in their brothels. ${ }^{37}$ Both owners claimed not to know the girls had contracted a disease. However, the doctor giving evidence said the girls were visibly thin and sick, and six out of the seven were suffering from gonorrhoea and syphilis. Jordan insisted the magistrate sentence the brothel owners to three months imprisonment and a fine of $\$ 200 .{ }^{38}$ The colonial officials wanted a new amendment to the Protection of Women and Girls Ordinance, allowing for the forced removal of women and girls to have mandatory examination and treatment. ${ }^{39}$ The Colonial Office agreed, and the Bill was introduced in 1925. So, while social movement organisations continued to push for the end of brothel prostitution and the introduction of sex education, the imperial government stood its ground and continued to state that regulation was a necessary step in controlling the spread of disease.

In response, the feminist movement orchestrated a robust protest against the Colonial Office. Alison Neilans, the president of the AMSH, was tipped off about the new amendment to the Protection Act by the Bishop of Singapore. ${ }^{40}$ She immediately wrote to Leo Amery, Secretary for the Colonies, to have the Bill reversed. In her letter, she claimed that 'the new legislation is a further attempt to get rid of diseased women and secure healthy women for the tolerated 
brothels'. ${ }^{41}$ She called for an end to compulsory examinations. ${ }^{42}$ The women's movement claimed that the mandatory examination of women was an act of inequality against women and girls perpetrated by the Colonial Office. The AMSH did not agree with the double standard of women being examined and not their male counterparts. She also drew attention to an earlier report by Professor Bostock Hill which highlighted that eliminating all prostitution was not possible, but 'the destruction of the commercial interest (procuring, exploiting, brothel-keeping) aims a blow at the vilest forms of prostitution which are inevitably associated with the traffic in women and children'. ${ }^{43}$ Neilans addressed the Colonial Office thus:

This matter is arousing a very considerable interest among various organisations interested in social hygiene and questions of the traffic in women. I know my committee is expressing the views of many other organisations in deploring the fact that you have approved the recent amendment to the Women and Girls Protection Enactment of the Federated Malay States. ${ }^{44}$

Neilans knew how to draw in other social movement organisations to her cause. She persuaded them to imagine they were all part of a community that shared in the struggle for women's rights in both England and distant lands. She sent letters to church and secular women's groups to protest the Colonial Office ruling. ${ }^{45}$ She asked Lady Astor and Sir Robert Newman, both members of the House of Commons, to address Parliament and to request Amery, the Colonial Office Secretary, (June 29, 1927), in recalling the Advisory Committee to the Colonies to access the new amendment. ${ }^{46}$ Amery considered it unnecessary to call the former Committee together, claiming 'the amendment has received my approval' ${ }^{47} \mathrm{He}$ also stressed the amendment had been enacted to protect women and girls. This paternal argument was repeatedly used to justify the colonial regulation of prostitutes and brothels. 
Neilans turned to the British Social Hygiene Committee (BSHC), thinking they would support her cause, but the BSHC made no move to oppose the government. According to Sybil Rolfe, Secretary of the BSHC, the new amendment 'is a harmless temporary arrangement' to stop the spread of disease. ${ }^{48}$ Neilans, furious at the position taken by the BSHC, berated Rolfe and her Committee for being paid off by the government. In a confidential letter to her colleague Miss Mary Shepherd, she claimed:

When a Society receives practically all its financial resources from the government and when the Colonial Office itself pays for all Mrs Rolfe and her colleagues expenses out to the far east, making a grant of 9,050 pounds for this purpose, then it is not easy for that council to turn around and criticise the government. ${ }^{49}$

Neilans faced harsh criticism. ${ }^{50}$ Rolfe contended that the AMSH was 'ill-informed and fanatical' with 'little knowledge of the conditions of the organisation and even less about the control of venereal disease in the colonies. ${ }^{51}$ In defence, Neilans declared:

The enlightenment of this country has been due to the work of this Association since 1870, and it was not achieved by refraining from drastic public criticism out of consideration for the feelings of the government. ${ }^{52}$

Neilans claimed that Josephine Butler had started these protests several decades before, which ended with the repeal of the Contagious Diseases Ordinance (CDO). At the same time, Neilans capitalised on the Josephine Butler Centenary celebrations to request politicians and the National Council of Women (NCW) to send resolutions demanding the Colonial Office bring back the Advisory Committee, end the mandatory examinations of women and girls, and 
abolish tolerated brothels. Neilans was adamant that the FMS 'frame their policy with the aim of removing the stimulus to the traffic in women provided by a brothel system' ${ }^{53}$

Up to this point, the BSHC was supportive of the regulation of brothel prostitution as a means to contain venereal disease, but also agreed with the Bostock Hill Report that venereal disease could be addressed through propaganda, free treatment and education. The trouble between the AMSH and the BSHC was subsiding, but not before Rolfe influenced Frank Sempkins, Secretary of the NVA to her way of thinking. Sempkins agreed with the criticism levelled at the AMSH, and 'felt the method of presenting the objection was, itself open to criticism, in that it imputed unworthy motives to men who are actuated by the highest motives' ${ }^{54}$

He firstly supported the colonial perspective and sided with the men in the colonies. What we see here is a masculine united front, but this did not last for long. After Henry OrmsbyGore (from the Colonial Office) refused to meet Sempkins to discuss the issue, he blamed the Colonial Office for the trafficking problems in the East:

\footnotetext{
'The general question of the existence of brothels in the British Colonies tolerated or controlled by legislation ...makes it abundantly clear that it is the existence of such institutions which make possible the continuance of the traffic in women and children' ${ }^{55}$
}

Despite the disparity between the sexes in the FMS, Sempkins argued 'it is not in keeping with the traditions of our country to permit such acquiescence because of difficulties'. Sempkins relented and deemed that some brothels were necessary, so "the obvious remedy was to close the worst houses and raise the standard of the others' ${ }^{56}$ The NVA agreed that working-class brothels of the 'vilest forms' had to be outlawed, but higher-class brothels could continue to operate. Debates around prostitution (regulation or prohibition) were convoluted; 
colonial administrators and their enthusiasts saw prostitution as a service, whereas feminists and other opponents saw prostitution as a service that required rescue. In response to these demands, Amery was compelled to set up an independent committee to determine the situation in the FMS. In 1928, a committee under the control of Earl Balfour, which included representatives from the BSHC, inquired into the Protection of Women and Girls legislation in the SS, FMS and UFMS. ${ }^{57}$ The committee questioned the usefulness of state regulation to curb disease and agreed legalised brothel prostitution was the cause of trafficking in Southeast Asia. ${ }^{58}$ With few other options, in 1929 the Colonial Office endorsed the gradual closure of all brothels under the Suppression of Brothels Bill. ${ }^{59}$ The last known brothel was closed in February 1931.

Colonial emotions around tolerated brothels and abolition versus social hygiene education

Brothels had been made illegal for the first time in the colonisation of Malaya. Trafficking and prostitution had been regulated for over 40 years, and most colonial officers and Chinese members of the communities had a hard time accepting the changes. According to the colonials, the Balfour Committee and members of the BSHC consisted of people who knew little of the state of affairs in the colonies. ${ }^{60}$ According to one newspaper editor, Malaya had been singled out by the unqualified and referred to as the 'cesspool of the East,' and for this unenviable distinction he claimed:

we have to thank successive committees of unqualified experts sitting at the other side of the world and having no knowledge of local conditions which have seen fit consistently to ignore the advice and appeals of Governors and men of science who have studied the problem on the spot. ${ }^{61}$ 
The colonial wrath over closing the brothels continued into the 1930s, with most of the anger aimed at the BSHC. The AMSH shifted its focus to other locations, but the BSHC - including male and female members -continued to work in the area of sexual hygiene education. In the earlier period, the BSHC supported the call for the amendment to allow the reintroduction of mandatory examinations. After relentless pressure from the AMSH, the BSHC changed its tune and recommended the elimination of brothels in the FMS and the introduction of social hygiene education. In response to its change in attitude, the colonial officials called the BSHC 'a collection of busybodies' and 'self-appointed reformers'. ${ }^{62}$ A number of scathing letters and editorials passed between the BSHC and the editor of the Straits Times. ${ }^{63}$ The BSHC believed that propaganda and free medical treatment decreased the numbers of those suffering from venereal disease. The editor argued the decrease was due to the economic depression and the reduction in labour. Supporting regulated prostitution, he believed the incidence of syphilis increased after brothels closed their doors. ${ }^{64}$

The conversation around displaced morality and disease continued, and most colonials didn't waver in their stance around regulated brothels and fulfilling men's 'natural' desires. Palgrave Simpson, a member of the FMS Legislative Council, stressed that brothels had existed throughout history and 'it is hopeless to try and make people moral by grandmotherly legislation'. ${ }^{65}$ After referring to the moral convictions of the $\mathrm{BSHC}$, he argued that prostitution was not shameful in Malaya because male workers outnumbered women and brothels were 'a ready outlet for the natural desires that are implanted in human beings' ${ }^{66}$ Simpson believed the objectives of the Bill were dictated in England by people 'who are not conversant with our conditions'. He was convinced there would be an increase in sexual crimes. An editor asserted that it was time that the Victorian minds of a section of the British public understood that 'prostitution is an essential part of the social fabric, that it has always 
been, is now and always will be a necessary social adjustment' ${ }^{67} \mathrm{He}$ went on to say that in Malaya, 'there are here tens of thousands of wage-earners who cannot afford to maintain a wife. Undisturbed by any quasi-moral considerations, they have to share a woman. ${ }^{68}$ Colonials continued to view women as objects of desire in a masculine colonial space and to dub the Chinese working classes as inferior to white men to justify their colonisation of the territory and the sexual violence against women and girls.

Medical doctor Sir David Galloway shared the editor's sentiments and saw regulated prostitution as a necessary practice. He criticised the notion that propaganda and education would work to stop the spread of venereal disease. Galloway called for the return of the CDO and brothel regulation. He argued that, under the regulation regime, 'disease will disappear, traffic in women and girls will cease, as also the open indecency of our streets, all of which flourish under the vapid instructions we are forced to follow'. He claimed that instead of following France in legalising prostitution, Britain was becoming emotional around morality and prostitution.

When Great Britain comes into line with other countries, we may hope that she will cease her insensate persecution of the prostitute, will stop her sloppy quasi-moral sentimentality and deal with the whole subject as one of public health. ${ }^{69}$

In fact, after watching the educational film Damaged Lives, Galloway argued, 'it may have conveyed a meaning to a small minority, but it was quite over the heads of the mass of people whom it was supposed to instruct'.$^{70}$ In berating the system of abolition and education, Galloway's comments continued to highlight notions of white superiority over colonised peoples and the necessity to protect women and girls from colonised men. Most of the colonials agreed that the traffic in women and girls was monstrous, but, except for religious 
leaders, most decided that under colonial regulation, women and girls had protection. The Chinese Protector argued that, before the repeal, no woman or girl could enter or leave the brothel without the consent of the Protector of Chinese who took particular care that she "was acting on her own accord and not under compulsion'. ${ }^{71}$ They saw trafficking as the result of the Chinese cultural practice of selling children.

The Chinese middle class, however, blamed tolerated brothels for the traffic in women and children. ${ }^{72}$ Most of the Chinese elite, particulary the few on the Legislative Committee, agreed it was necessary to close the brothels and stop 'lower' class girls from prostitution. At the same time, Chinese elites decided that some brothels were necessary. The local church leaders, however, supported abolition and believed that 'moral propaganda societies working among Asiatic youths are most desirable'.$^{73}$ As the Chinese middle class increased, they became more concerned with liberal humanity and Chinese male morality. They established girls' homes for trafficking victims, a destitute Chinese emergency fund for Chinese women including prostitutes over the age of 45 years, and called for Chinese men to stay away from prostitutes. However, this had more to do with the morality and health of middle-class Chinese men than the welfare of women and girls.

Prostitutes from brothels to criminals in coffee shops

After brothels were outlawed in Malaya, the prostitute community dispersed, many repatriated to China and Japan at the expense of the government; some found marriage partners, a few committed suicide and others continued to work in 'illegal' brothels in the FMS tin-mining towns and capital cities. ${ }^{74}$ The women found clandestine prostitution their only option because few other jobs were available. In 1929, seven Cantonese females were found prostituting in a 
Chinese hotel in Kuala Lumpur. In 1930, six Chinese girls aged between 16 and 22, together with six men, were found in a coffee shop near a pineapple factory. ${ }^{75}$ The police increased surveillance around coffee shops, boarding houses and other sites used for illegal brothels. Laws such as the Boarding Houses Act were enacted to prevent landlords from leasing their premises to prostitutes. This restricted the movement and security of women and girls to a large extent. According to the Attorney General, 'there was no intention of harassing individual prostitutes', the legislation was to ensure that owners or lessees did not use their premises as brothels. ${ }^{76}$ Nevertheless, women and girls continued to face harassment, especially in coffee shops.

Missionaries in Hong Kong informed the AMSH that coffee shops and sing-song dwellings in Malaya acted as fronts for brothels. ${ }^{77}$ Consequently, policing escalated along with further correspondence to the Colonial Office. At the same time, the Coffee Shop Guild agitated for the government to ban women from working in coffee shops. ${ }^{78}$ The guild claimed 'the employment of women led to unfair and expensive competition and placed the store with pretty girls at an unfair advantage'. ${ }^{79}$ The Police Commissioner agreed that 'the waitress' or 'prostitute' provided criminals with revenue. ${ }^{80}$ While the secret societies did not control trafficking, illegal brothels allowed the secret societies to use standover tactics to extort money from the women and girls. The Kuala Lumpur Sanitary Board nevertheless blamed the secret sociteies for the traffic in women and girls:

The objection of this department to the employment of waitresses is related to the exploitation of women for trade purposes ... it is used by the trafficker in women and girls to bring victims before the public., 81 
In 1931, it was decided not to allow women to work in coffee houses, outdoor eateries or licensed houses. ${ }^{82}$ There was no mention of the hardship that women faced trying to find a job during the depression years. Closing the doors to employment in coffee shops and other entertainment outlets continued to push women into street prostitution. ${ }^{83}$ It did not stop the traffic of women and girls.

\section{Trafficking in the FMS}

After trafficking was enacted as an international crime, the colonials increased surveillance around the movements of women and girls across national borders. Photographs and letters were exchanged by police and colonial officials between Hong Kong, Singapore and the Malay states. From these letters, the Secretariat for Chinese Affairs in Hong Kong flagged suspicious cases to the Secretariat in Singapore and Malaya. The correspondence included the names of the women and the circumstances of their migration. ${ }^{84}$

By the 1930s, immigration and police checks intensified in the FMS and the number of detectives and police reached 4349; one policeman for every 394 inhabitants. ${ }^{85}$ The police, along with detectives, were positioned in railway stations to look for suspicious cases. Posters were hung in post offices, ports, police stations, railway stations and boarding houses to create awareness. The International Vigilance Association and the League of Nations organised the poster displays as part of the international surveillance around trafficking and they heightened the level of fear around kidnap and rape. For example:

All women and girls are warned to avoid strangers, whether men or women, who may address them when making any journey. There are many men and women whose object is to decoy or kidnap young 
women or girls to selling them as prostitutes or for other immoral purposes. If any woman or girls fall into the hands of such procurers or procuresses, she should endeavour to have information conveyed to the nearest Police Station. ${ }^{86}$

These surveillance tactics put pressure on procurers, traffickers and brothel owners as well as women and girls migrating for prostitution to avoid detection. After the Singapore government closed the working-class brothels, the movement of women and girls from Singapore to Malaya increased, but this only lasted until the police and immigration officials caught up. ${ }^{87}$ After that, the supply coming from Singapore to Malaya decreased. According to the reports:

The prohibition in the Straits Settlements of the entry of avowed prostitutes had had an effect upon the supply of Chinese prostitutes to brothels in the FMS, as almost all Chinese immigration comes through the port of the colony. ${ }^{88}$

The reports indicated that procurers continued to buy or abduct women in Canton. ${ }^{89}$ Between 1926 and 1931, there were 16 prosecutions and charges laid against traffickers between China and the FMS. In the UFMS, there were four cases of trafficking. ${ }^{90}$ However, according to the Protector in Kedah, 'the girls did not desire to be rescued'.

Preventing women and girls from being trafficked or migrating for prostitution through the ports in the Straits Settlements only increased the movement of women and girls across land borders of the nearby countries and colonies. In 1929, there were numerous reports of 'offences discovered' in the Kedah and Johor regions. ${ }^{91}$ In the Kedah region, the women and girls were brought through Siam (Thailand) and the Dutch East Indies (Indonesia) to the UFMS of Kedah near Penang. The traffic in Thai women and girls also intensified via Siam..$^{92}$ Thai women did 
not usually work in the FMS and formed a new supply of women and girls to the FMS.$^{93}$ Thirty Thai women were discovered in brothels in Ipoh, Perak, and there were a few others in Kuala Lumpur. In the Johor region, women also moved from the sly brothels in Singapore to the increasing red-light districts in the towns of Muar, Batu Pahat, and Johor Bahru in the UFMS. According to the Protector, due to increased surveillance, 'the girls were taken to Muar where they worked in opium dens' ${ }^{94}$

From here on, the League requested reports on both the international movement of women and girls through sea ports and the movement between states across land borders. In 1931, there were 11 cases of national traffic and four cases of international traffic. ${ }^{95}$ National traffic reports highlighted the numbers of procurers caught transferring women between the Malay states and securing new women along the way. Laws were enacted to punish all traffickers caught procuring women for prostitution locally and internationally. There was always a certain amount of fluidity in the movement of women and girls between brothels, between states and, actual international trafficking, but the colonial officials failed to distinguish between traffickers, procurers and the procuress. In some cases, it was difficult for the Protector to prosecute because the women and girls refused to implicate the person accused of trafficking. Some cases were more complicated than others, and colonial officers were often manipulated by the women and girls, or the procurer and trafficker. ${ }^{96}$

However, several traffickers were convicted and sentenced for three to six months incarceration, and others for as long as 12 months. In the FMS, there were reports of Malay, as well as Chinese men, charged with trafficking and living off prostitutes earnings. ${ }^{97}$ Under the Banishment Act, 'traffickers, especially repeat offenders, were banished from the colony for life. Twenty-three traffickers were deported between 1926 and 1930; of these, 18 were 
Chinese women, four Chinese men and one Javanese man. ${ }^{98}$ More women than men were fined, incarcerated and deported for trafficking and kidnapping, thus, forcing women and girls into prostitution. These women were, for the most part, older sex workers who had turned their hand to procuring women and girls to the FMS and they formed part of a long-established migration network between Japan, China, Hong Kong and Southeast Asia.

The new bureau, set up in Thailand to collect and collate information from participating countries, continued to highlight the trafficking of women and girls from China to Malaya. The report included full particulars of men and women convicted or suspected of trafficking including their photographs and fingerprints. It was especially important to include the information of individuals not convicted (due to lack of evidence) and other suspected traffickers who escaped conviction. The names of these people were passed on to port authorities, steamship companies and immigration departments as persons of interest. This was an essential element in the League of Nations surveillance tactics around border control.

\section{Conclusion}

The period between 1920 to 1940 saw the rise of internationalism around migration and trafficking in women and girls. Paradoxically, the League of Nations started legal and social action that addressed trafficking, but at the same time constructed the 'trafficker'. The term 'migration for prostitution' disappeared under the League legislation and women migrating for prostitution were criminalised. Migratory prostitution, although distinct from criminal sex trafficking, was perceived as trafficking. The grey areas between the trafficked and the traffickers were not addressed because the League of Nations worked within the framework of victims and perpetrators. The League legacy lives on, and feminist scholars continue to 
debate the meaning of 'trafficking'; some agree that all migratory prostitution is trafficking, and others find it challenging that all women and girls migrating for commercial sex are labelled 'victims'. This case study on Malaysia highlights the difficulties in understanding what trafficking occurs across national borders and what strategies are necessary to combat trafficking.

The case study of interactions between social movement organisations, the British government and colonial officers also show how colonialism and humanitarianism clashed in early responses to trafficking. Colonial attitudes based on race and sexism compromised the humanitarian efforts of the international and social movements. Colonial officials saw Malaya as a masculine space and refused to abolish prostitution. The League of Nations had little success in getting the Colonial Office to end the regulation of brothels in the colonies until the women's movement in England finally undermined the colonial position around prostitution (considered the impetus for trafficking). The amendment to the law allowing mandatory examinations of women and girls provided the AMSH with the opportunity to organise a protest movement, not just against the new amendment, but in opposition to the practice of regulating tolerated brothels in the British Empire. While the motives overlapped, the AMSH effectively invoked the political support of other women's organisations in closing down the brothels for the good of the Empire. Empire was idealised, but at the same time justified the actions around female welfare and equality.

By exploring the contribution of the League of Nations, AMSH and the NVA responses to trafficking and prostitution, this article provides new insights with significant primary sources to the historiography of trafficking and empire. It has shown that sex trafficking is entwined 
with British colonial expansion, the migration of male workers and tolerated brothels in Southeast Asia.

\section{References}

A Despicable Trade: Importing Kidnapped Girls from Siam (Malaya Tribune 7 January 1925: 8).

A Public Danger: Chinese Brothel Keepers Severely Punished. (The Straits Times 10 September 1925).

A Social Question of Malaya. (The Singapore Free Press and Mercantile Advertiser 11 May 1928: 9).

Association for Moral and Social Hygiene (1927) Resolution re Federated Malay States, November 1927, Women's Library, London School of Economics, Malaya 3AMS/D/40

Attwood, R, Stopping the Traffic: The National Vigilance Association and the International Fight against the 'white slave' trade 91899-c. 1909) Women's History Review 24, no. 3 (2015): 325-350.

Bandoeng Conference Resolutions: Stricter Measures to be Adopted. (The Straits Times. 19 February 1937: 17).

Bell, S. Reading, Writing and Rewriting the Prostitute Body. Indianapolis, Indiana University Press. 1994.

Brothels in Malaya: Full Report of Home Committee (Malay Tribune, 1 May 1929: 12).

Chairman Sanitary Board. Memorandum from the Sanitary Board, Kuala Lumpur

Concerning the Employment of Women in Coffee Shops. Sel. G. 2411/1931.

Chinese Protector Selangor. Reports on Visits and Inspection to Brothels. Kuala Lumpur. Chinese Sec. 11/ 689/1894.

Closer Co-Operation toward a Common End: Tributes to Malaya's Pioneer Work. (The Straits Times 19 February 1937: 12).

Cockman H J. Under Secretary to the Government FMS. The Subject of the Employment of Women as Waitresses in Coffee-shops and Eating-houses. Kuala Lumpur 1932, Sel. G. 2411/1932.

Colonial Office. Prostitution and VD in Malaya. 1926. CO 273 538/5.

Commissioner of Police to the Resident of Selangor, Kuala Lumpur Sel. G. 2411/1931 CP $1020 / 1931$. 
Crowdy, R. The Humanitarian Activities of the League of Nations. Journal of the Royal Institute of International Affairs 6, no. 3 (1927): 153-169.

Dame Katherine Furse, Letter to Alison Neilans 7 December 1927 Women's Library, London School of Economics, Malaya 3AMS/D/40.

Garcia, M. R. The League of Nations and the Moral Recruitment of Women. International Institute voor Sociale Geschiedenis Special Edition 57: (2012): 97-128.

Goodman A M (Acting) Secretary for Chinese Affairs, S. S. Annual Report of the Secretary for Chinese Affairs, Straits Settlements for the Year 1926. Sel. Sect. 2563/1927.

Gorman, D. Empire, Internationalism and the Campaign against the Traffic in Women and Children. Twentieth-Century British History 19, no. 2 (2008): 186-216.

Gronewold, S. Beautiful Merchandise New York, Harrington Park Press 1985.

Jacobsen, T. Sex Trafficking in Southeast Asia: A History of Desire, Duty and Debt. New York, Routledge 2016.

John, J. Protector of Chinese. Memorandum Concerning the Employment of Waitresses in Licence Houses to the Resident of Selangor Sel. G. 2411/1931.

Laite, J. A. The Association for Moral and Social Hygiene: Abolitionism and prostitution law in Britain (1915-1959). Women's History Review 17, no. 2 (2008): 207-223.

League of Nations Annual Reports on Traffic in Women and Children 1928 for the Federated Malay States. League of Nations 1928-1932 Registry no. 11B, 11817 / 9305.

League of Nations Annual Reports on Traffic in Women and Children 1930 for the Unfederated Malay States. League of Nations 1928-1932 Registry no. 27249- 25849.

League of Nation Reports for the States of Johore, Kedah, Perlis, Kelantan and Brunei for the Year 1929 on the Traffic in Women and Children.

League of Nations. Traffic in Women and Children: Obscene Publications; Summary of Annual Reports for 1931, Secretariat Series of League of Nations Publications Geneva 1932. IV Social 1932. IV 7.

League of Nations. Warning from the Secretary for Chinese Affairs to all women and girls' in Annual Reports on Traffic in Women and Children, Straits Settlements 1928, Geneva 1929: Archives 1928-1932.

League of Nations. Traffic in Women and Children: Summary of Annual Reports for 1929. Geneva 1930, League of Nations: 34.

League of Nations. Commission of Enquiry into Traffic in Women and Children in the East: Report to the Council. League of Nations Publications. Geneva 1932. IV Social IV 8.

Lees, L. H. Discipline and Delegation: Colonial Governance in Malayan Towns 1880-1930. Urban History 38, no. 1 (2011): 48-61. 
Legg, S. The Life of Individuals as well as of Nations': International Law and the League of Nations' Anti-Trafficking Governmentalities." Leiden Journal of International Law 22, (2012): 647-664.

Levine, P. Prostitution Race and Politics: Policing Venereal Disease in the British Empire. New York, Routledge. 2003.

Lock, T. C. Letter to the Bishop. Women's National Library. London School of Economics Malaya 1928, 3AMS/ D/40.

Malaya's Social Hygiene Laws: Changes Opposed "Suppression" Policy Endorsed. Report of Colonial Office Committee. (The Straits Times 29 April 1929: 12).

McClintock, A. Imperial Leather, Race Gender and Sexuality in the Colonial Conquest. New York, Routledge.1995.

Metzger, B. Towards an International Human Rights during the Inter-War Years. In K. Grant, P. Levine and F. Trentmann (eds). In Beyond Sovereignty: Britain Empire and Transnationalism c. 1880-1950. Hampshire, Palgrave Macmillan 2007: 54-79.

Neilans, A. Correspondence between the Association for Moral and Social Hygiene and the Secretary of State for the Colonies, 1927 CO 273/539/5.

Neilans, A. Letter to Mrs Neville Rolfe, Secretary British Social Hygiene Committee. (24 November 1927). Women's National Library, London School of Economics AMS /D/40/05.

Neilans, A. Letter to Amery, Colonial Office. Women's Library, London School of Economics, Malaya 3AMS/D/40.

Neilans, A. Letter to Miss Grace Steinbeck at American Bible Society, Shanghai, China 8 March 1928 Women's Library London School of Economics, Malaya 3AMS/D/2.

Neilans, A. Confidential Letter to Miss M. Shepherd 8 December 1927 Women's Library London School of Economics, Malaya 3AMS/D/40.

Neilans, A. (ed) Regulated Prostitution within the British Empire, The Shield, August September 1919, AMSH, London Malaya 3AMS/D/40.

Neilans, A. to the AMSH Executive Committee (Confidential) Rough Notes on BSHC Letter 10 December 1927 Women's Library, London School of Economics, Malaya 3AMS/D/40.

Plan to Abolish White Slave Traffic: All Licences must be Prohibited. (The Straits Times 30 May 1933: 15).

Pedersen S. The Maternalist Moment in British Colonial Policy: The Controversy over 'Child Slavery' in Hong Kong. The Past and Present Society 171, (2001): 161-202.

Prostitution is a necessary social adjustment. (Morning Tribune, 6 June 1938: 8.

Protector of Chinese. Annual Report on the Chinese Protectorate, Selangor and Negeri Sembilan for the Year 1920. Kuala Lumpur, Sel. Sec. 755/1921. 
Protector of Chinese. Annual Report on the Chinese Protectorate, Selangor for the Year 1924. Kuala Lumpur, Sel. Sec. 848/1925.

Reports for the States of Johore, Kedah, Perlis, Kelantan and Brunei for the Year 1929 on the Traffic in Women and Children. H.C.O. 1930, 35/1030.

Secretary of the Moral and Social Hygiene Committee. Tolerated Brothels within the British Empire: The New Situation in the Federated Malay States. London, 1927, AMSH: 1-4.

Sempkins, F. National Vigilant Association, Letter to Gerald H Creasy, Private Secretary to Ormsby Gore, Colonial Office 1 The Vigilance Record April 1928 Women's Library, London School of Economics, Malaya 3AMS/D/21.

Sempkins, F. National Vigilance Society Letter to Colonial Office, 14 July 1927. Women's Library, London School of Economics AMS /D/40/05.

Sir Robert Newman, Letter to Alison Neilans 20 July 1927 Women's Library, London School of Economics, Malaya 3AMS/D/20.

Spongberg, M. Feminizing Venereal Disease: The Body of the Prostitute in NineteenthCentury Medical Discourse. London, MacMillan Press Ltd. 1997.

Suppression of Brothels: Grandmotherly Legislation. (The Singapore Free Press and Mercantile Advertiser 27 August 1930).

Sybil Neville Rolfe, British Social Hygiene Council, Letter to the Under Secretary of State, the Colonial Office 8 November 1927. CO 273/539/5.

The Archbishop Advisory Board for Preventative and Rescue Work, Letter to Alison Neilans 3 April 1924 Women's Library, London School of Economics, Malaya 3AMS/D/40.

The Balfour Committee: SSA Against Altering Present Legislation. (The Straits Times. 11 July 1928: 8).

The Ostriches. (The Straits Times, Thursday 1 November 1928: 8).

The Ostriches. (The Straits Times 5 August 1933: 10).

The Ostriches, The Same Old Jargon on Prostitution. (The Straits Times 14 September 1936: $3)$.

The Ostriches Again. (The Straits Times 14 January 1937: 10).

Traffic in Women and Children: The Far Eastern Inquiry, Malaya Tribune 29 October 1930: 3.

Warren, J. Karayuki-San of Singapore: 1877-1941. Journal of the Malaysian Branch of the Royal Asiatic Society 62, (1989): 45-79.

Warren, J. Ah Ku and Karayuki-San: Prostitution in Singapore, 1870-1940. New York, Oxford University Press.1993. 
Wilson, H. M. On Some Causes of Prostitution: With Special Reference to Economic

Conditions. London, Association for Moral and Social Hygiene, 1916.

Yeng Ah Hee, Petition Letter to the Resident Secretary, Selangor, 16 June 1924, Kuala

Lumpur, Akib Negara.

${ }^{1}$ Chinese Protector Selangor. Reports on Visits and Inspection to Brothels. Kuala Lumpur. 1894

${ }^{2}$ Yeng Ah Hee, Petition Letter to the Resident Secretary, Selangor, 16 June, 1924, Kuala Lumpur

${ }^{3}$ Jacobsen, T. Sex Trafficking in Southeast Asia: A History of Desire, Duty and Debt. New York, Routledge

${ }^{4}$ The regulation of migration and brothel prostitution in Southeast Asia situated within the cultural gendering of colonial society, imperial discourses of race and sexualities, imperial anxieties over sodomy and the spread of venereal diseases. Warren, J. Ah Ku and Karayuki-San: Prostitution in Singapore, 1870-1940. New York, Oxford University Press.1993

${ }^{5}$ Gorman, D. Empire, Internationalism and the Campaign against the Traffic in Women and Children. 2008: 186-216.

${ }^{6}$ Pedersen S. The Maternalist Moment in British Colonial Policy: The Controversy over 'Child Slavery' in Hong Kong. 2001: 161-202

${ }^{7}$ Garcia, M. R. The League of Nations and the Moral Recruitment of Women. 2012, p. 99.

${ }^{8}$ Ibid., p. 100.

${ }^{9}$ Attwood, R. Stopping the Traffic: The National Vigilance Association and the International Fight against the 'white slave' trade 91899-c. 1909) 2015, p. 332

${ }^{10}$ Neilans, A. (ed) Regulated Prostitution within the British Empire, The Shield, August - September, 1919, AMSH, London

${ }^{11}$ According to Laite the foreign prostitute was believed to have the capacity to pass immorality onto the innocent English girl. Laite, J. A. The Association for Moral and Social Hygiene: Abolitionism and prostitution law in Britain (1915-1959) 2008, p. 208

12 Ibid., p. 213

${ }^{13}$ McClintock, A. Imperial Leather, Race Gender and Sexuality in the Colonial Conquest. 1995, p. 288.

${ }^{14}$ Ibid.

15 SMO's included both international and national such as the IBSTWC, AMSH, the Jewish Association for the Protection of Jewish Girls and Women and the International Abolition Federation.

${ }_{16}$ Gorman, D. 2008 op cit. p. 198

${ }_{17}$ Legg, S. The Life of Individuals as well as of Nations': International Law and the League of Nations' Anti-

Trafficking Governmentalities." Leiden Journal of International Law 22, (2012): 647-664

${ }^{18}$ Crowdy, R. The Humanitarian Activities of the League of Nations. Journal of the Royal Institute of International Affairs 1927, p. 156

${ }^{19}$ Metzger, B.Towards an International Human Rights during the Inter-War Years. In K. Grant, P. Levine and F. Trentmann (eds). In Beyond Sovereignty: Britain Empire and Transnationalism c. 1880-1950. Hampshire, Palgrave Macmillan 2007: 54-79. p. 67

20 Crowdy op cit., p. 157

${ }^{21}$ Ibid., p. 169

${ }^{22}$ Wilson, H. M. On Some Causes of Prostitution: With Special Reference to Economic Conditions. London, Association for Moral and Social Hygiene 1916: 15.

${ }^{23}$ Ibid 
${ }^{24}$ Traffic in Women and Children: The Far Eastern Inquiry, Malaya Tribune, 29 October 1930. Page 3

${ }^{25}$ The report was discussed in great detail at the $12^{\text {th }}$ Session of the Advisory Commission for the Protection and Welfare of Children and Young People held in Geneva in 1933. Plan to Abolish White Slave Traffic: All Licences must be Prohibited. (The Straits Times 30 May 1933: 15)

${ }^{26}$ National Vigilance Society to Colonial Office, 14 July, 1927.

${ }^{27}$ Bandoeng Conference Resolutions: Stricter Measures to be Adopted. (The Straits Times. 19 February 1937: 17).

${ }^{28}$ Protector of Chinese. Annual Report on the Chinese Protectorate, Selangor and Negeri Sembilan for the Year 1920.

${ }^{29}$ League of Nations. Commission of Enquiry into Traffic in Women and Children in the East: Report to the Council. Series of League of Nations Publications. 1932.

${ }^{30}$ Protector of Chinese. Annual Report on the Chinese Protectorate, Selangor for the Year 1924.

${ }^{31}$ Protector of Chinese. 1920. op.cit.

${ }^{32}$ Protector of Chinese. 1924. op.cit.

${ }^{33}$ Levine, P. Prostitution Race and Politics: Policing Venereal Disease in the British Empire. New York, Routledge. 2003.

${ }^{34}$ Bell, S. Reading, Writing and Rewriting the Prostitute Body 1994.; Spongberg, M. Feminizing Venereal

Disease: The Body of the Prostitute in Nineteenth-Century Medical Discourse 1997.

${ }^{35}$ Levine 2003, op.cit.

${ }^{36}$ Goodman A M (Acting) Secretary for Chinese Affairs, S. S. Annual Report of the Secretary for Chinese Affairs, Straits Settlements for the Year 1926.

${ }^{37}$ A Public Danger: Chinese Brothel Keepers Severely Punished. (The Straits Times 10 September 1925).

${ }^{38}$ Ibid.

${ }^{39}$ Colonial Office (1926). Prostitution and VD in Malaya.

${ }^{40}$ The Archbishop Advisory Board for Preventative and Rescue Work, Letter to Alison Neilans 3 April 1924

Women's Library London School of Economics, Malaya 3AMS/D/40

${ }^{41}$ Neilans, A. Secretary for the Association for Moral and Social Hygiene, Letter to Amery, Colonial Office, Women's Library, London School of Economics, Malaya 3AMS/D/40

${ }^{42}$ Secretary of the Moral and Social Hygiene Committee. Tolerated Brothels within the British Empire: The

New Situation in the Federated Malay States. London 1927

${ }^{43} \mathrm{Ibid}$

${ }^{44}$ Neilans, A. (1927) Correspondence between the Association for Moral and Social Hygiene and the Secretary of State for the Colonies CO 273/539/5

${ }^{45}$ Association for Moral and Social Hygiene (1927) Resolution re Federated Malay States, November 1927

Women's Library London School of Economics, Malaya 3AMS/D/40

${ }^{46}$ Sir Robert Newman Letter to Alison Neilans, 20 July, 1927 Women's Library London School of Economics, Malaya 3AMS/D/20

${ }^{47}$ Tolerated Brothels within the British Empire: The New Situation in the Federated Malay States The Association for Moral and Social Hygiene, October 1927. CO 273/539/5

${ }^{48}$ Sybil Neville Rolfe, British Social Hygiene Council, Letter to the Under Secretary of State, the Colonial Office 8 November, 1927. CO 273/539/5

${ }^{49}$ Alison Neilans, Confidential Letter to Miss M. Shepherd 8 December, 1927 Women's Library London School of Economics, Malaya 3AMS/D/40

${ }^{50}$ Dame Katherine Furse, Letter to Alisan Neilans, 7 December 1927 Women's Library London School of Economics, Malaya 3AMS/D/40

${ }^{51}$ Alison Neilans to the AMSH Executive Committee (Confidential) Rough Notes on BSHC Letter and Neilans

Responses, 10 September 1927 Women's Library London School of Economics, Malaya 3AMS/D/40

${ }^{52}$ Ibid

${ }^{53}$ Ibid

${ }^{54}$ Sempkins, F. Letter to Gerald H Creasy, Private Secretary to Ormsby-Gore Colonial Office. National Vigilant Association, 1928 The Vigilance Record Women's Library London School of Economics, Malaya $3 \mathrm{AMS} / \mathrm{D} / 21$

${ }^{55} \mathrm{Ibid}$

${ }^{56}$ Ibid

${ }^{57}$ Brothels in Malaya: Full Report of Home Committee (Malay Tribune, 1 May 1929: 12)

${ }^{58} \mathrm{Ibid}$

${ }^{59}$ Malaya's Social Hygiene Laws: Changes Opposed "Supression" Policy Endorsed. Report of Colonial Office Committee. (The Straits Times 29 April 1929: 12)

${ }^{60}$ A Social Question of Malaya. (The Singapore Free Press and Merchantile Advertiser 11 May 1928: 9) 
61 The Ostriches. (The Straits Times, Thursday 1 November 1928: 8)

${ }^{62}$ The Ostriches. (The Straits Times 5 August 1933: 10).

63 The Ostriches The Same Old Jargon on Prostitution. (The Straits Times 14 September 1936: 3)

64 The Ostriches Again. (The Straits Times 14 January 1937: 10)

${ }^{65}$ Suppression of Brothels: Grandmotherly Legislation. (The Singapore Free Press and Mercantile Advertiser

27 August 1930)

${ }^{66}$ Ibid.

${ }^{67}$ Prostitution is a necessary social adjustment.( Morning Tribune, 6 June 1938: 8)

${ }^{68}$ Suppression of Brothels: Grandmotherly Legislation. op. cit.

${ }^{69}$ Ibid

${ }^{70}$ Prostitution is a necessary social adjustment. op.cit.

${ }^{71}$ Protector of Chinese. Annual Report on the Chinese Protectorate, Selangor for the Year 1929.

${ }^{72}$ Traffic in Women and Girls: Chinese Statement and SS Reply, Malayan Tribune, 5 February 1937, page 11

${ }^{73}$ Dr Lock Letter to the Bishop, Kuala Lumpur. 29 November 1928.

${ }^{74}$ See Warren, J. Karayuki-San of Singapore: 1877-1941.1989: 45-79.

${ }^{75}$ League of Nations. Traffic in Women and Children: Summary of Annual Reports for 1929.

${ }^{76}$ Suppression of Brothels op cit.

${ }^{77}$ Neilans, A. Letter to Miss Grace Steinbeck at American Bible Society, Shanghai, China 8 March, 1928

Women's Library London School of Economics, Malaya 3AMS/D/21

${ }^{78}$ Chairman Sanitary Board. Memorandum from the Sanitary Board, Kuala Lumpur Concerning the

Employment of Women in Coffee Shops.1931

${ }^{79}$ John, J. Chinese Protector. Memorandum to the Resident of Selangor Concerning the Employment of

Waitresses in Licence Houses. 1931

${ }^{80}$ Commissioner of Police (FMS) to the Secretary to the Resident of Selangor. 1931

81 John. J, Protector of Chinese Selangor and Pahang (1931) Memorandum, G 2411/31.

${ }^{82}$ Cockman H J Under Secretary to the Government Federated Malay States. Subject of the Employment of

Women as Waitresses in Coffee-shops and Eating-houses. 1931

${ }^{83}$ Chairman Sanitary Board (1931) op cit.

${ }^{84}$ Trafficked women and underage girls were detained in Girls Homes to investigate their position and make recommendation. Some were married to local non Malays mostly Chinese and others were repatriated to their country of origin. Some however were kept in the homes until they reached the age of consent. In some cases the girls were sent to the Lock hospital to determine their virginity or if they suffered from venereal disease.

${ }^{85}$ Lees, L. H. Discipline and Delegation: Colonial Governance in Malayan Towns 1880-1930.

${ }^{86}$ League of Nations . 'Warning from the Secretary for Chinese Affairs, to all women and girls' in Annual Reports on Traffic in Women and Children, Straits Settlements 1928.

${ }^{87}$ League of Nations. Traffic in Women and Children: Obscene Publications; Summary of Annual Reports for 1931 p. 8.

${ }^{88}$ League of Nations. Commission of Enquiry into Traffic in Women and Children in the East: Report to the Council. Series of League of Nations Publications. 1932

${ }^{89}$ League of Nations. Traffic in Women and Children: Obscene Publications op cit.

${ }^{90}$ League of Nations (1931). Annual Reports 1930. UFMS

${ }^{91}$ Reports for the States of Johore, Kedah, Perlis, Kelantan and Brunei for the Year 1929 on the Traffic in Women and Children.

92 A Despicable Trade : Importing Kidnapped Girls from Siam (Malaya Tribune 7 January 1925: 8)

${ }^{93}$ League of Nations. 1932. op. cit.

${ }^{94}$ League of Nations. Traffic in Women and Children: Obscene Publications op cit.

95 Ibid

${ }^{96}$ League of Nations. Annual Reports on Traffic in Women and Children 1928 for FMS.

${ }^{97}$ Ibid

${ }^{98}$ League of Nations. 1932. op. cit.

${ }^{99}$ Closer Co-Operation toward a Common End: Tributes to Malaya's Pioneer Work. (The Straits Times 19 February 1937: 12). 